\title{
A Review on Fuel Cell as Advanced Power Source
}

\author{
S.K. Kamarudin, W.R.W. Daud, M.S. Ayub, A.W. Mohammad, S. Takriff and S. E. Iyuke* \\ Department of Chemical and Process Engineering, \\ National University of Malaysia, 43600 UKM Bangi, Selangor, Malaysia. \\ *Department of Chemical and Environmental Engineering, \\ University Putra Malaysia, 43400 Serdang, Selangor, Malaysia.
}

Fuel cells are making headlines across the globe in almost all arenas of power production. While the technology for these electrochemical power plants was invented around 1839 and has been in use for nearly 150 years, it is only recently that fuel cells have gained popular recognition and reckoned for serious consideration as a power zone for the future. Despite their relatively new arrival on the popular scene, fuel cells have already found their way into pre-commercial testing in domestic, commercial, industrial and mobile applications. Fuel cells convert chemical energy of a fuel gas directly into electrical work, and are efficient and environmentally clean, since no combustion is involved. Fuel cells are presently under development for a variety of generation application in response to the critical need for a cleaner energy technology. The use of fuel cell systems has been strongly promoted in Japan and the United States for medium-scale co-generation plants. Nowadays, this interest has been extended to the smaller scale, in particular at the residential area level. All fuel cells currently being developed for near term use in electric vehicles require hydrogen as a fuel. At the same time, increased interest has arisen for the application of fuel cell systems to automotive propulsion, although there is no clear option on the direct use of hydrogen stored on board or the installation of hydrogen plant on board as of this time. This paper outlines the acute global population growth and the growing need and use of energy and its component as well as its environmental impact. In particular, this paper reviews the existing or emerging fuel cells technologies, limitations, and their benefits in connection with energy, environment and sustainable development relationship. In addition, this paper also explores fuel sources and the various types of fuel cells as well as their applications.

\section{INTRODUCTION}

Energy produced from fossil fuel (coal, oil and natural gas) is not environmentally friendly. Apart from this, the availability of fossil fuels become a limiting factor when pollution increases and the demand for alternative energy sources like solar (Lee et.al 2002; Li \& Wang 2002; Tiba et.al 2002) nuclear power (Ohnishi 2002; Galy et.al 2002; Schrempel et.al 2002; Meyendorft et.al 2002), wind power (Bansal et.al 2002; Manwell et.al 2002; Eskander 2002; Liu et.al 2002) and hydrogen and oxygen fuel cells become inevitable resource. The amount of energy produced from solar power is limited (Datta et.al 2002) and control problem arises due to variances of PV (Photovoltaic) output power under different isolation levels (Shatter et.al 2002). In addition, energy efficiency is low. In the case of nuclear power, waste generation is very dangerous to both man and environment. For safe and clean energy, fuel cell and wind energy sources are preferred.

The problem with energy supply and use is related not only to global warming but also to 
Table 1: Population, Energy and Electrictty demands (Million of barrels per day of oll equivalent)

\begin{tabular}{|l|c|c|c|}
\hline Year & Population (billion) & $\begin{array}{l}\text { Energy demands, } \\
\text { MBDOE }\end{array}$ & $\begin{array}{l}\text { Electricity demands, \% } \\
\text { Energy demand }\end{array}$ \\
\hline 1940 & 2.4 & 70 & - \\
\hline 1960 & 3.0 & 90 & - \\
\hline 1970 & 3.6 & 100 & 6 \\
\hline 1985 & 4.8 & 200 & 12 \\
\hline 1995 & 5.3 & 300 & 15 \\
\hline 2000 & 6.1 & 350 & 30 \\
\hline 2001 & 7.2 & 410 & 50 \\
\hline
\end{tabular}

Source: World Energy Council 1998

environmental concerns such as air pollution, acid precipitation, ozone depletion, forest destruction and radioactive substance emission. World population keeps increasing at $1.2-2 \%$ per year, such that it is expected to reach 12 billion in 2050 (Stambouli et.al 2002). Therefore, economic development will almost certainly continue to grow. Global demand for energy services is expected to increase by as much as an equal order of magnitude by 2050 , while primary-energy demands are expected to increase by 1.5 to 3 times (World Energy Council 1998; refer to Stambouli et.al 2002) as seen in Table 1.

As world wide supplies dwindle (Figure 1), the development of new power generation technologies will become increasingly important. Simultaneously, interest will likely increase regarding energy-related environmental concerns. Indeed, energy is one of the main factors that must be considered in the discussion of sustainable development. In response to the critical need for a cleaner energy technology, some potential solutions have envolved. This includes energy conservation through improved energy efficiency, reduction in the consumption of fossil fuels, and an increase in the supply of environment-friendly energy, such as renewable sources and fuel cells. Electricity from fuel cells can be used in the same way as grid power.

\section{TYPE Of FUel CELL}

A fuel cell, by definition, is an electrical cell, which unlike storage cells, can be continuously fed with a fuel so that the electrical power output is sustained indefinitely. Fuel cells function on the principle of electrolyte charge/exchange between a positively-charged anode plate on a negativelycharged cathode plate.

When hydrogen is used as the basic fuel, reverse hydrolysis occurs, yielding only water and heat as byproducts while converting chemical energy into electricity, as shown in Figure 2. Pollutant emission is practically zero.

Overall reaction:

$2 \mathrm{H}_{2}$ (gas) $+\mathrm{O}_{2}$ (gas) $\rightarrow 2 \mathrm{H}_{2} \mathrm{O}+$ energy

Fuel cells are generally categorized by electrolyte material. As shown in figure 2 , there are five main types of fuel cells.

Table 2 present the summary of different fuel cell technologies, their principle characteristics, 
Table 2: Different Fuel Cell Technologies and Main Technical Characteristic.

\begin{tabular}{|c|c|c|c|c|c|c|c|}
\hline Type of Fuel Cell & $\begin{array}{c}\text { Operating } \\
\text { Temperature } \\
\left({ }^{\circ} \mathbf{C}\right)\end{array}$ & Electrolyte & Type of Electrolyte & Fuel & Oxidant & $\begin{array}{c}\text { Water } \\
\text { generated }\end{array}$ & $\begin{array}{l}\text { Efficiency } \\
(\%)\end{array}$ \\
\hline Alkaline (AFC) & $50-200$ & $\begin{array}{l}\text { Potassium hydroxide, } \\
\text { generally in aquas } \\
\text { solution, at } 35 \% \text { in } \\
\text { weight }\end{array}$ & $\begin{array}{l}\text { Liquid: circulating or in } \\
\text { a matrix }\end{array}$ & $\begin{array}{l}\text { Pure hydrogen, or } \\
\text { hydrazine }\end{array}$ & $\mathrm{O}_{2} / \mathrm{Air}$ & Anode & $50-55$ \\
\hline $\begin{array}{l}\text { Direct Methanol } \\
\text { (DMFC) }\end{array}$ & $60-200$ & $\begin{array}{l}\text { Proton exchange } \\
\text { membrane (e.g. Nafion) }\end{array}$ & $\begin{array}{l}\text { Solid: polymer which } \\
\text { has to be moistened }\end{array}$ & Liquid methanol & $\mathrm{O}_{2} / \mathrm{Air}$ & Cathode & $40-55$ \\
\hline $\begin{array}{l}\text { Phosphoric acid } \\
\text { (PAFC) }\end{array}$ & $160-210$ & Pure Phosphoric acid & $\begin{array}{l}\text { Liquid: in a porous } \\
\text { matrix of silicon } \\
\text { carbide }\end{array}$ & $\begin{array}{l}\text { Hydrogen from } \\
\text { hydrocarbons and alcohol }\end{array}$ & $\mathrm{O}_{2} / \mathrm{Air}$ & Cathode & $40-50$ \\
\hline $\begin{array}{l}\text { Sulfuric acid } \\
\text { (SAFC) }\end{array}$ & $80-90$ & Pure Sulfuric acid & $\begin{array}{l}\text { Liquid: in a porous } \\
\text { matrix of silicon } \\
\text { carbide }\end{array}$ & $\begin{array}{l}\text { Alcohol or impure } \\
\text { hydrogen }\end{array}$ & $\mathrm{O}_{2} / \mathrm{Air}$ & Cathode & $40-50$ \\
\hline $\begin{array}{l}\text { Proton Exchange } \\
\text { Membrane } \\
\text { (PEMFC) }\end{array}$ & $50-80$ & $\begin{array}{l}\text { Proton exchange } \\
\text { membrane (e.g. Nafion }\end{array}$ & $\begin{array}{l}\text { Solid: polymer which } \\
\text { has to be moistened }\end{array}$ & $\begin{array}{l}\text { Less pure hydrogen from } \\
\text { hydrocarbons or } \\
\text { methanol }\end{array}$ & $\mathrm{O}_{2} / \mathrm{Air}$ & Cathode & $40-50$ \\
\hline $\begin{array}{l}\text { Molten } \\
\text { Carbonate } \\
\text { (MCFC) }\end{array}$ & $630-650$ & $\begin{array}{l}\text { Old generation: } \\
\mathrm{Li}_{2} \mathrm{CO}_{3} / \mathrm{K}_{2} \mathrm{CO}_{3} \\
\mathrm{New}_{\text {generation: }} \\
\mathrm{Li}_{2} \mathrm{CO}_{3} / \mathrm{Na}_{2} \mathrm{CO}_{3}\end{array}$ & $\begin{array}{l}\text { Liquid: in a porous } \\
\text { matrix of lithium } \\
\text { aluminates }\end{array}$ & $\begin{array}{l}\text { Hydrogen, carbon } \\
\text { monoxide, natural gas, } \\
\text { propane, marine diesel }\end{array}$ & $\begin{array}{c}\mathrm{CO}_{2} / \mathrm{O}_{2} / \\
\mathrm{Air}\end{array}$ & Anode & $50-60$ \\
\hline $\begin{array}{l}\text { Solid Oxide } \\
\text { (SOFC) }\end{array}$ & $600-1000$ & $\begin{array}{l}\text { Ceramic as stabilized } \\
\text { zirconium and doped } \\
\text { perovskite }\end{array}$ & Solid (ceramics) & Natural gas or propane & $\mathrm{O}_{2} / \mathrm{Air}$ & Anode & $45-60$ \\
\hline
\end{tabular}

(Source: Bernay et.al 2002; Stambouli et.al 2002)

Table 3: Current Material of the Different Fuel Cell Technologies

\begin{tabular}{|c|c|c|c|}
\hline Technology & Anode & Cathode & Bipolar plates \\
\hline PEMFC & $\begin{array}{l}\text { Carbon cloth, carbon } \\
\text { particles with high specific } \\
\text { area, platinum particles, } \\
\text { weight } 0.1 \mathrm{mgcm}^{-2} \text {, PTFE, } \\
\text { Nafion@ }\end{array}$ & $\begin{array}{l}\text { Carbon cloth, carbon } \\
\text { particles with high specific } \\
\text { area, platinum particles, } \\
\text { weight } 0.3 \mathrm{mgcm}^{-2} \text {, PTFE, } \\
\text { Nafion@ }\end{array}$ & $\begin{array}{l}\text { Machined carbon or } \\
\text { stainless steel }\end{array}$ \\
\hline DMFC & $\begin{array}{l}\text { Carbon cloth, carbon } \\
\text { particles with high specific } \\
\text { area, platinum-ruthenium } \\
\text { particles, weight } 2 \mathrm{mgcm}^{-2} \text {, } \\
\text { PTFE, Nafion@ }\end{array}$ & $\begin{array}{l}\text { Carbon cloth, carbon } \\
\text { particles with high specific } \\
\text { area, platinum-ruthenium } \\
\text { particles, weight } 2 \mathrm{mgcm}^{-2} \text {, } \\
\text { PTFE, Nafion@ }\end{array}$ & $\begin{array}{l}\text { Machined carbon or } \\
\text { stainless steel }\end{array}$ \\
\hline $\mathrm{AFC}$ & $\begin{array}{l}\text { Hydrophobic layer (PTFE), } \\
\text { carbon catalyst (platinum } \\
\text { particles with } 0.3 \mathrm{mgcm}^{-2} \\
\text { loading or cobalt-based } \\
\text { catalyst }\end{array}$ & $\begin{array}{l}\text { Hydrophobic layer (PTFE), } \\
\text { carbon catalyst (platinum } \\
\text { particles with } 0.3 \mathrm{mgcm}^{-2} \\
\text { loading or cobalt-based } \\
\text { catalyst }\end{array}$ & $\begin{array}{l}\text { Current collection by } \\
\text { nickel mesh and } \\
\text { distribution of gases, } \\
\text { water and electrolyte } \\
\text { with plastic frame }\end{array}$ \\
\hline PAFC & $\begin{array}{l}\text { Carbon cloth as a support, } \\
\text { catalyst layer: PTFE }+ \\
\text { carbon black with high } \\
\text { specific area + platinum } \\
\text { particles } 0.1 \mathrm{mgm}^{-2}\end{array}$ & $\begin{array}{l}\text { Carbon cloth as a support, } \\
\text { catalyst layer: PTFE }+ \\
\text { carbon black with high } \\
\text { specific area + platinum } \\
\text { particles } 0.5 \text { mgcm }^{-2}\end{array}$ & Graphite \\
\hline MCFC & $\begin{array}{l}\text { Nickel-chromium ally with } \\
10 \mathrm{wt} . \% \text { chromium }\end{array}$ & Porous nickel oxide & $\begin{array}{l}\text { Stainless steel with } \\
\text { protective layers at } \\
\text { the anode and } \\
\text { cathodes sides }\end{array}$ \\
\hline SOFC & $\begin{array}{l}\mathrm{Ni} / \mathrm{YSZ} \text { cermet of } 30 \% \\
\text { porosity }\end{array}$ & $\begin{array}{l}\text { Strotium-doped lanthanum } \\
\text { mangnite of } 30 \% \text { porosity }\end{array}$ & $\begin{array}{l}\mathrm{LaCrO}_{3} \text { or } \mathrm{FeCr} \\
\text { alloy or stainless } \\
\text { steel depending on } \\
\text { the operating } \\
\text { temperature } \\
\end{array}$ \\
\hline
\end{tabular}




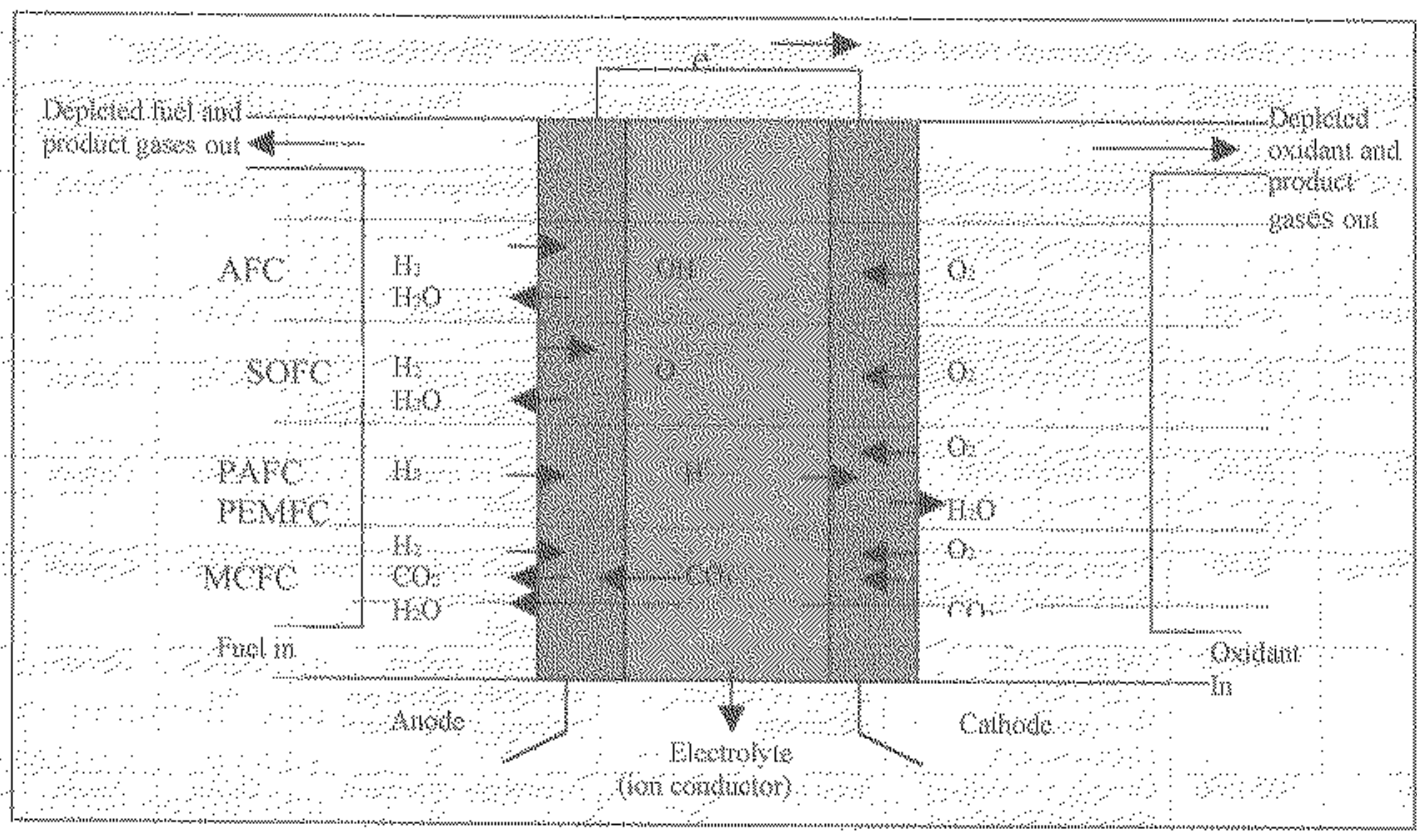

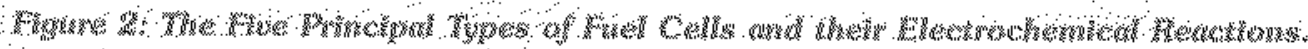

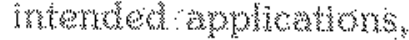
workmon developres and wher anderad

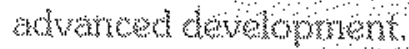
Most ofter fuek ond are

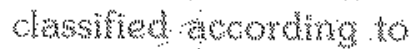

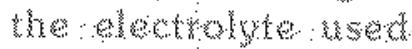
which setwer athe operatims tentorum Howeverwand

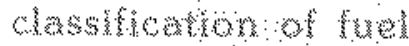

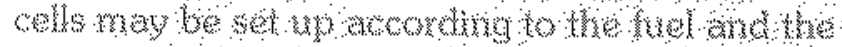

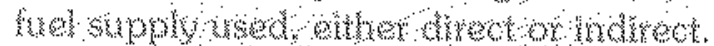

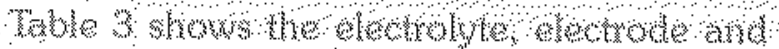

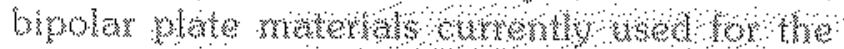

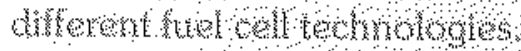

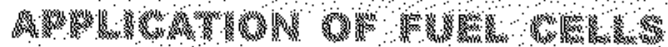

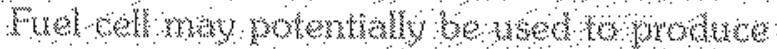

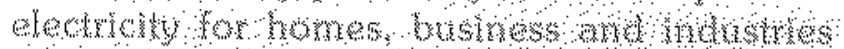

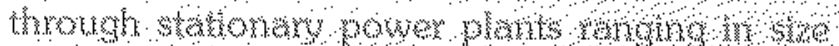

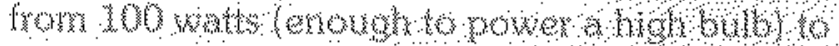

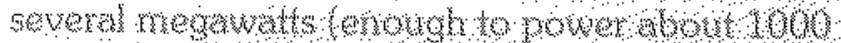

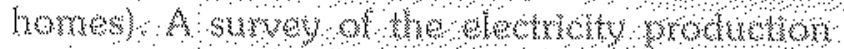

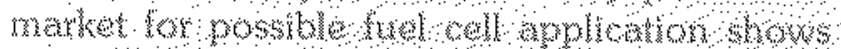

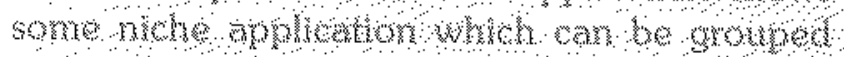

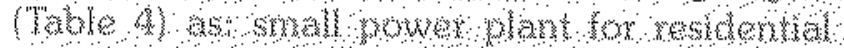

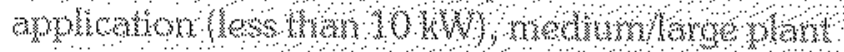

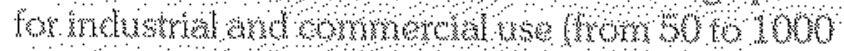

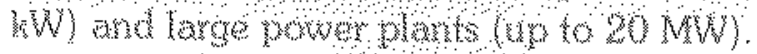

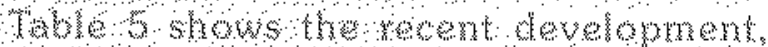
monded aprowon and man deveroper at wrow ypes of kederem

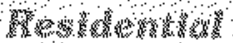

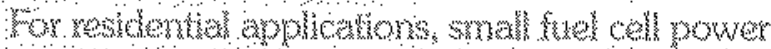

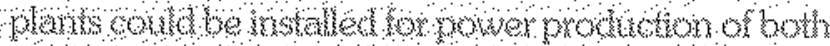

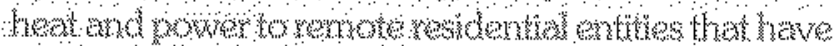

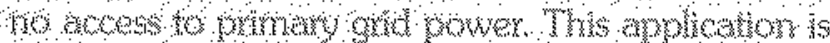

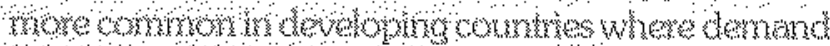

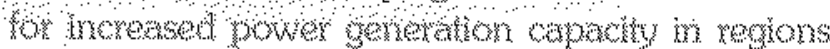

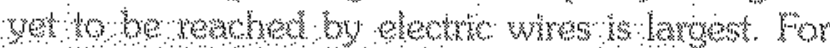

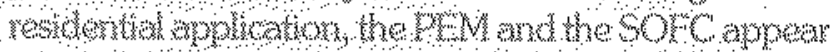

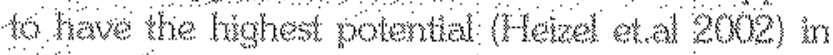

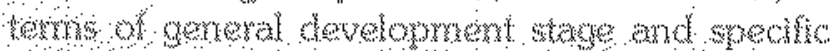

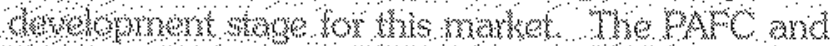

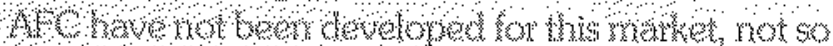

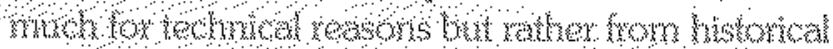

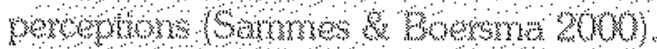




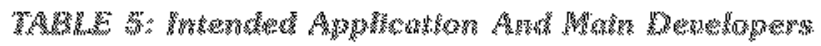

\begin{tabular}{|c|c|c|c|}
\hline 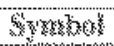 & 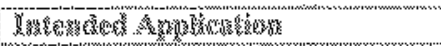 & 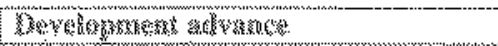 & 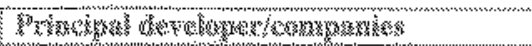 \\
\hline 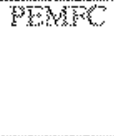 & 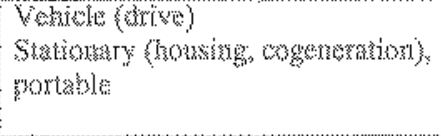 & 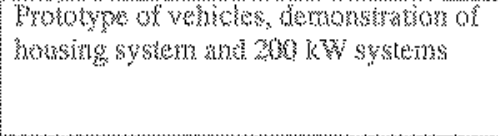 & 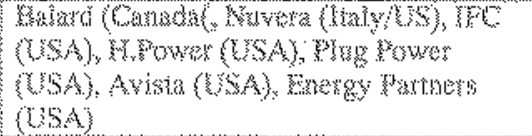 \\
\hline $\mathrm{AlO}$ & 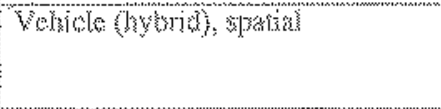 & 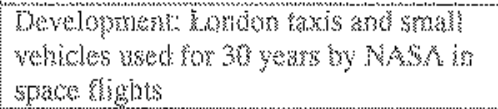 & 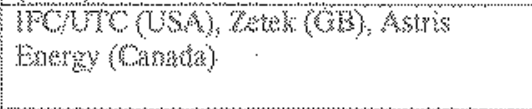 \\
\hline $\mathrm{W} M \mathrm{BC}$ & 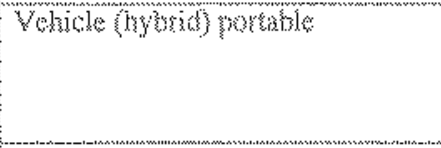 & 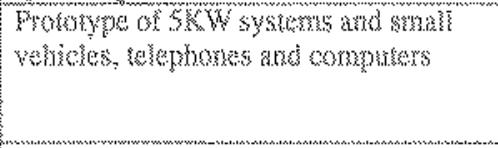 & 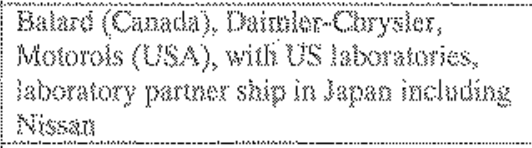 \\
\hline Pance & Stationary (cogernertion) & 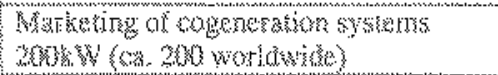 & 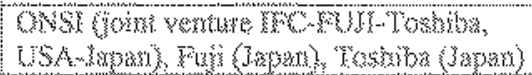 \\
\hline$M$ & 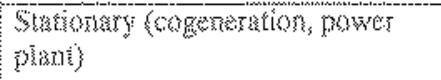 & 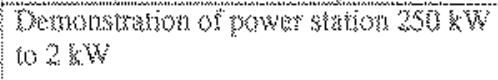 & 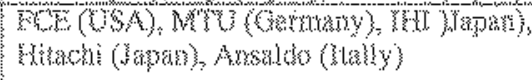 \\
\hline $50 \%$ & 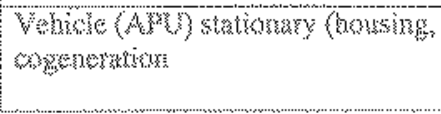 & 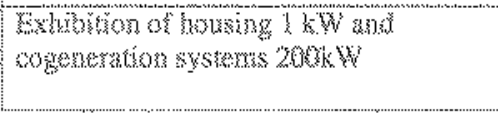 & 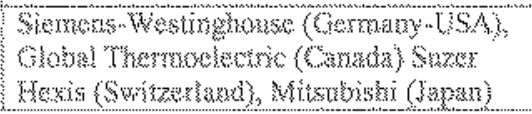 \\
\hline
\end{tabular}

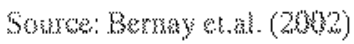

\section{Venderate}

A bey commercial ampination of tuen wals is their potential to replace the internal combuston

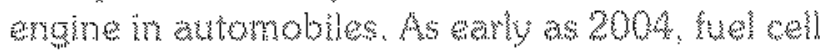
angrnes sould be implemented in more then 100,000 antomobie sald aromo the work

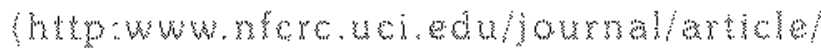
fcarticleindex.hm). All major atomobie manufacturers and several other companies are developing prototype funl coll vehioles to

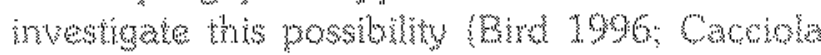

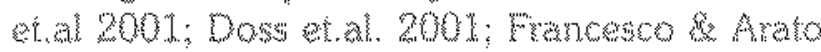

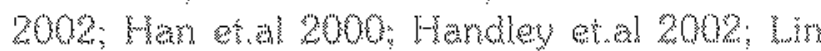
2000; ogeren 1999, pank 1908 ; Shm \& Les $2000)$

\section{powar storoge}

Another aspect of power wrokstion for which fuel colls are well auted is power storage. "hese can be used to store ereargy for uture use in power production (Hoio etal 1996. Watzobe etal

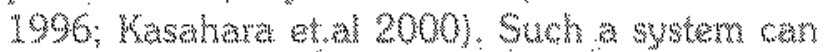
be used th confunction whth solw cells (Shater

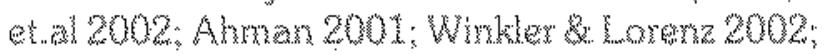

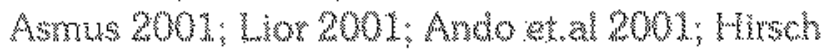

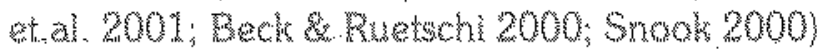
to store energy during the day ard prodtuce power ar night or with conventonal power whing to store erergy during of peak how and help meet load reguirements during periods of high electicity demand (Dufour 1998; Lee at al zoon; Womhamem 1998. Walmark 2002 Womaw 1998 .

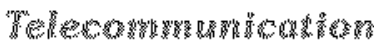

Intarest in wang tirel cells to power portiate

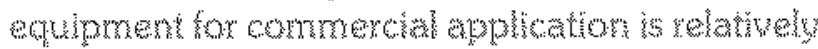
recent. This is perhags partly due to the surecoss of Li-based bateries in powaring laprom computers, mobiles phones, person digital

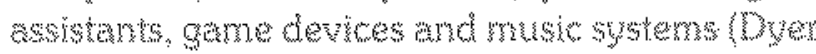
2002). The demand for wergy storde device that will allow the bevices to operate for longer

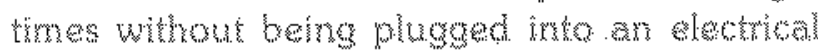

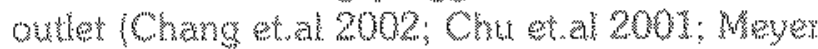

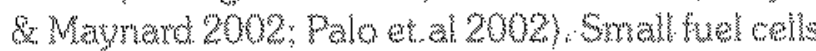
could be used 10 power telecommuntration satelthes, rephacing or augmentive solar panels

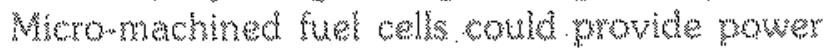
to comprys chips. Findlu, minute fuel cel could sefaly produce power for biological amplisation

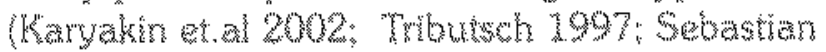
at. 1906 ) such as hearng aids and pecemekers.

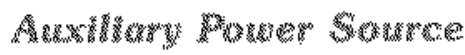

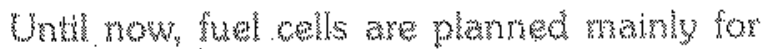
the snive application. Hokever, pher vehicle application may be considered for his power

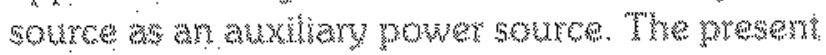

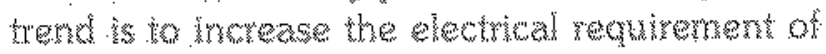
the vehicte aluxiliatrus, reduction of consumption 
and emission and satety devices. A tuel cell powar plant car be used as an auxinary sounce of power or Av capable of suppintrge thewer to venche

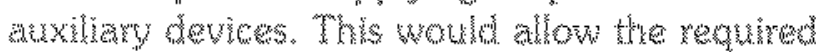
bettery power to be reduced, as well as, in the long term, to supposs the alternaton. (Benay etal 2002$, Cacciolu et at 2001$)$

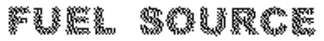

Fuel choice and fuel processing rechnology choice will be fundamental actors in the sucoess

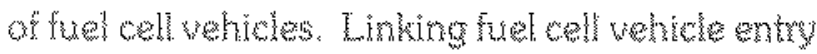
strategies on a specific atrernatye fust whth

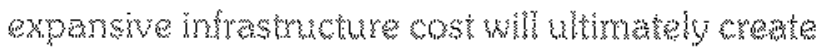
wel cost burders than exced the cost targets for

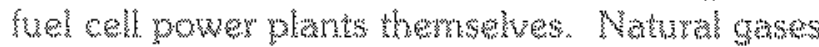

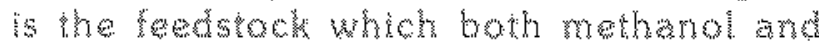
hydrogen are made most sconomically but stean

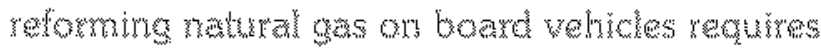
high tenperature thet demand lomo stert up times and a signiticant reducton in the vehicles frel economy. One altenatue soure sa fual cell oparating on stored hydrogen, whise currenty ofters energy dersite ranging from 500 to 1000

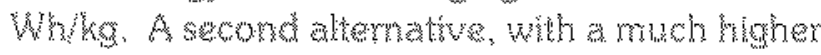

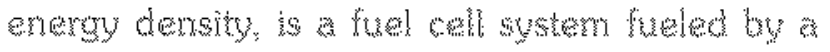

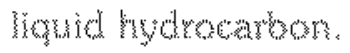

\section{Hydrogew}

Hydrogen ss the lightost he simplest and one of the most aburdant elements on rature. It always comes combined wh other elements and hes a varyery of gool propertives. Bot production

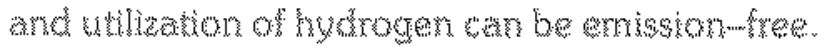

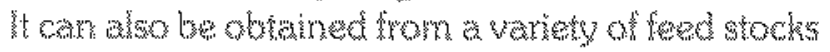

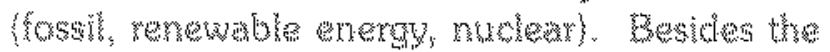

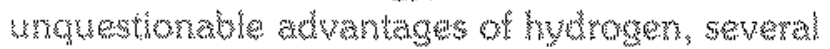
problems oceur in figveloping the reguired technologies: difwsion of hydroger as an enery

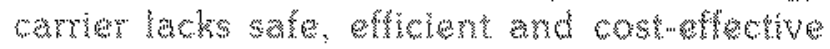
storage and the separtion and secuestration of

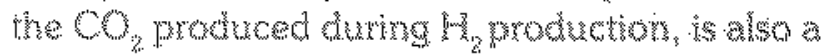
poimt of concern if not stored in safe locations. A key istue is how to arevide hydroden to the thet

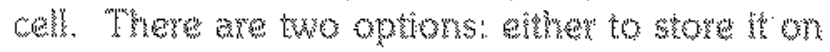
borkt the vehwe or to mroduse the hydrogen on tye vehictery means of a fuel processor /Bemay et. 2002, Bird 1996, Cunhe \&zovedo 2000;
Haw 2002, Edwards at al 1998; Hey at 2000;

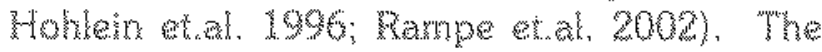
storage of hydrogen in chemicals has the disadvanduce of whe production step and the refomation wo hydroger. Vehicles with on board stean reforming of methanol or gasolne have

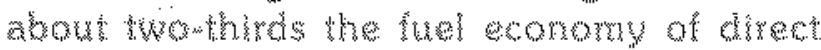
hydrogem wehieles (Ogdean at al 1999). "Wh afficien logses in hin un processor (losses in making

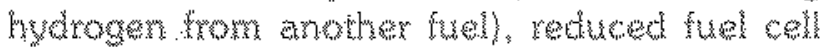

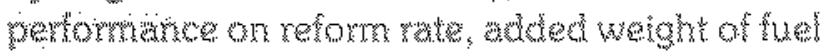
processor componerts, and eflects of dual

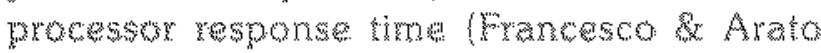
2002). Ever though the storage of hydrogera at Wigh presure in the gas phare resulds ru a bigh volume, is an economical and smple way to

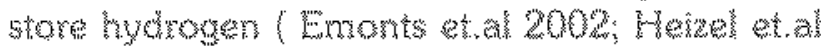
2002; strobel atal 2002)

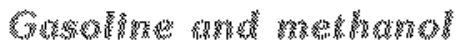

Casoline and methand are conswered as the

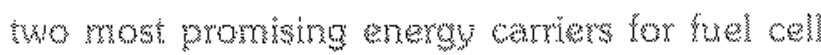

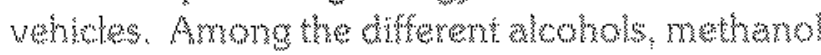
is the most proming organic fuel gecuse its use

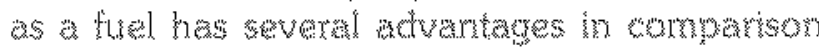
to hydrogen; high solubith ir agreons

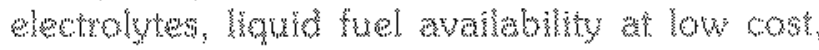
easily handed, ransponted and stored, and high

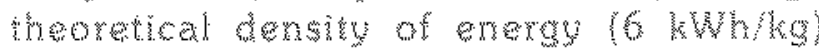

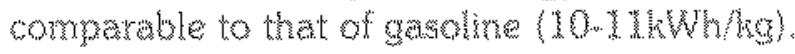

Metharal, hike byorogen is asso capable of colvering pow directy in suel sells whou the med for roming and this cleary simplites havmare and regponse characteristucs. Other alcohols, such as ethanol, enylene, glycol,

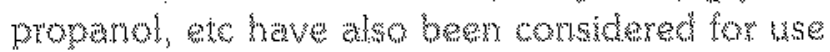

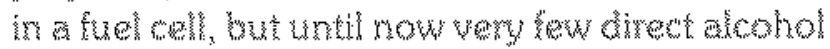
fuet cells (DAFC) (Lamy 2002) have been demonstrated, the rnost advanced sustem being the direct methand fur well (DMFC) (Cacciola

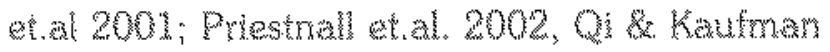

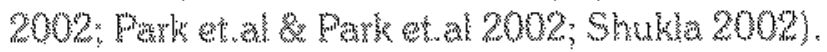

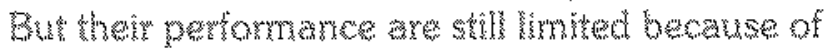
several problems: (1) the low activity of the state

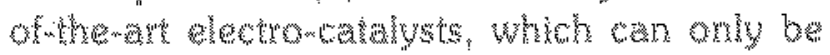
entumad by increasing the operating remperature. (2) anode poisoning by strongly

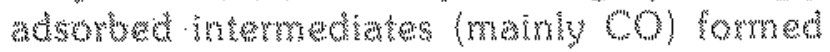


curing methand oxidation, and 12 ) the high extart

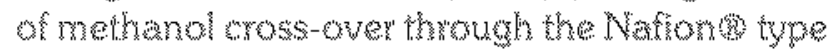

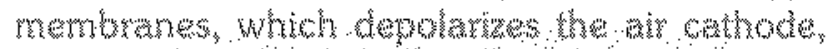

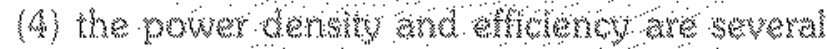

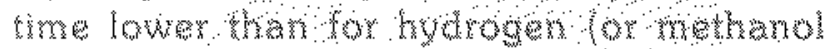

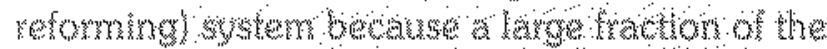

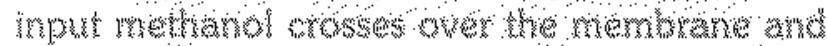

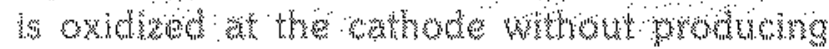
useful powex (Bro "1956), (5) Enhancement of the

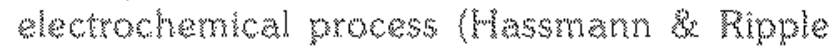
1998). Moreover, methand has a paricular

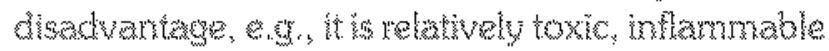
with a low boling point $(65 \mathrm{C})$, and it is not a primary hel nor a renewable fuel (Lamy 2002).

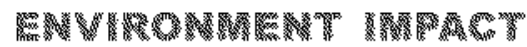

Emission of watbon lioxide $\left(\mathrm{CO}_{2}\right)$, the main green house gas (CHO) hom human activities.

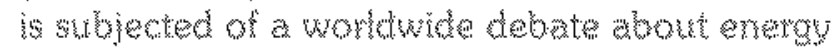

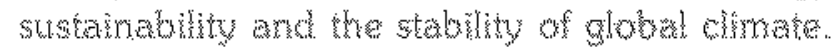

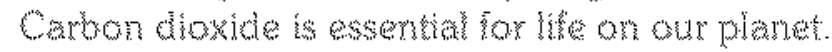

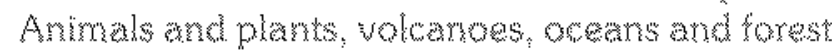
control.win a delicate wystem of complex

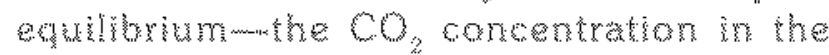

724.

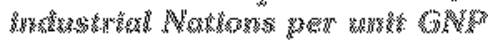

\begin{tabular}{|c|c|c|}
\hline TRank & Weston & $\mathrm{CO}_{3}$ \\
\hline 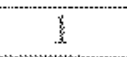 & Kkns & 7591 \\
\hline 2 & Chinatiat & 4015 \\
\hline 3 & USA & $7 / 10$ \\
\hline s. & Crexpata & 708 \\
\hline 5 & U & 349 \\
\hline 6 & Gormeny & 37. \\
\hline 7 & daly & 366 \\
\hline 8 & Japun & 271 \\
\hline 9 & Rrance & 255 \\
\hline
\end{tabular}

Somre: Stambentis $20 \mathrm{~m}$ atmosphere too low or two high vinges can lead

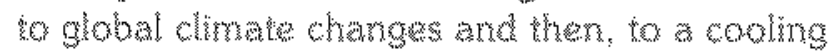

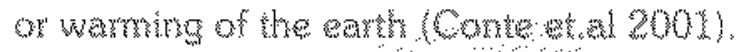

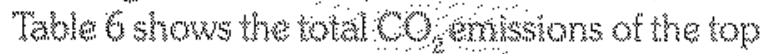

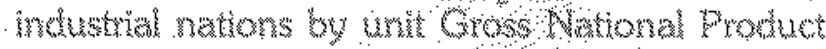

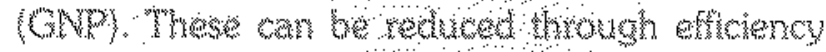

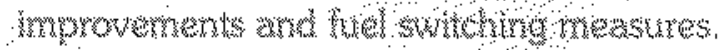

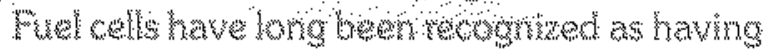

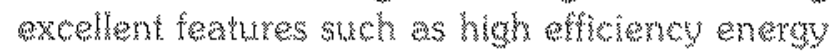

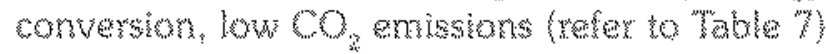

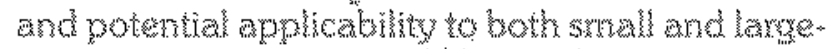
scale plans. Therefore, fur cells have been

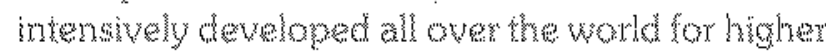

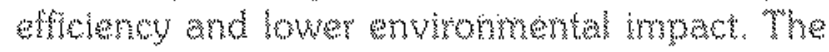
worse fective paranters for globul wamm are

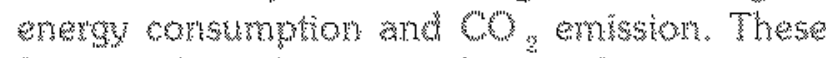
features show that reseawchers ane engiveers in any erergy related industry sliould sincerely consiber long-term strateries lon kewing the

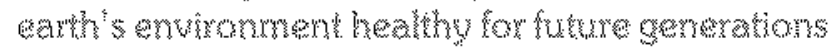

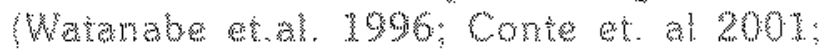
Francesco Are 2002 .

Both pertol and desel have been modelad by

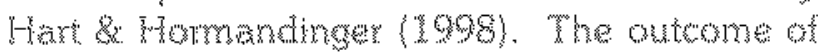

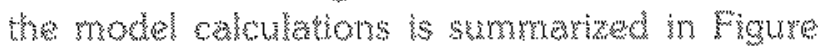
3. The envrommental beneth of fuel cell cars are clar: 00,50, NO and PM errissions are down by one to wo orders of mentute. Forthe netural gasweled hel car, PM emissions are

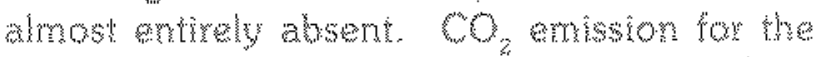
methanol car are $62 \%$ of the perch car $40 \%$ for the raturat gasmowerwe hel call war. Methene emiscions wise by around hall, from a low base of $0.04 \mathrm{~g} / \mathrm{km}$. This is a fuel switchures arect but it is

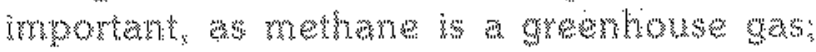
nevertheless reductions of up to $60 \mathrm{~g}$, in $\mathrm{CO}$, cam the overall global warming potemial (cW drop sinnificantly.

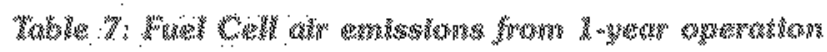

\begin{tabular}{|c|c|c|c|c|c|c|}
\hline 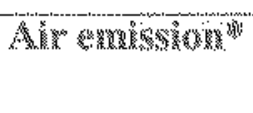 & Wo & $\mathrm{MVOX}$ & $\mathrm{BO}$ & 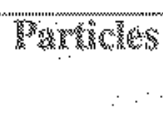 & 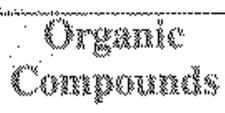 & $\mathrm{CO}_{2}$ \\
\hline $\begin{array}{l}\text { "owsing fucled } \\
\text { plant }\end{array}$ & 28,008 & 41,427 & 28,125 & 500 & 468 & $4,4,6,000$ \\
\hline Wustollo & 0 & 0 & 72 & 0 & 0 & $1,860,000$ \\
\hline
\end{tabular}

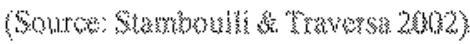

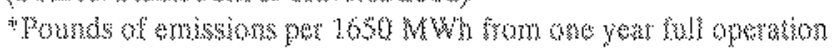




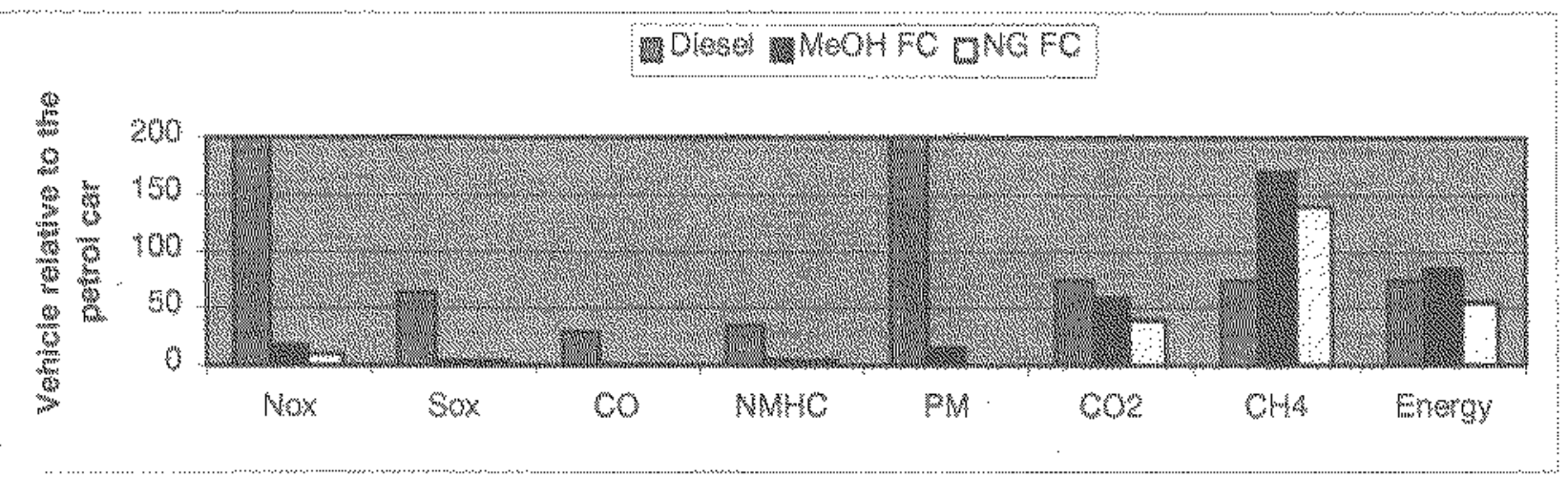

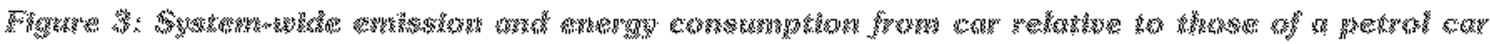

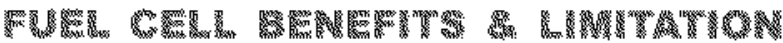

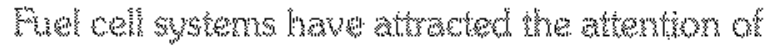
phose who are wherewter in energy woblems becutse of their advantageous characteristics as grouped im Table 8. Cost is the mator factor and it wit becme critical as wide spread commerwh us of the rew brodband devices ocums. There is presenty a severe basic cost pervaly as aswated with the we of

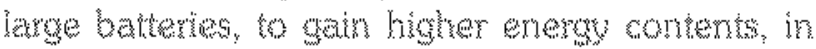

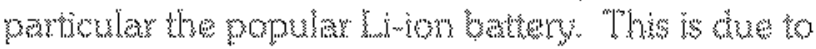
the relatwely higher cost of the basic batrevise

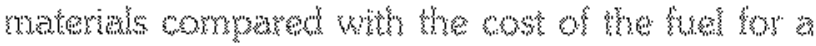
fuelomil.

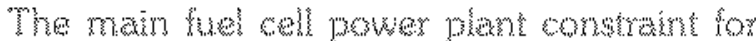

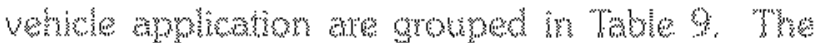
challenge for on board fuel coll is tre modumon of an efficient and compact unit to rebreve the demanding targets ser out for antomotive

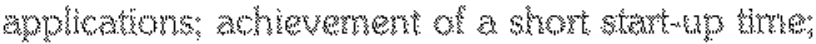
and efficisucy tor hydrogen gereration on a smail

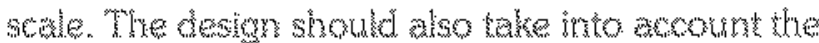
themal and ghysical integraton of components.

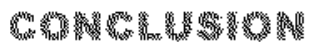

Oner the rext 5 yedrs, the diw

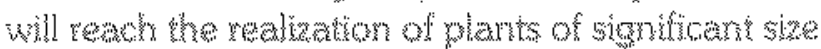

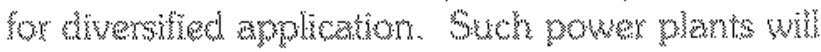
use hydrogen produced hon refoming and will be irrterrated with systern for $\mathrm{CO}_{2}$, semestwation and

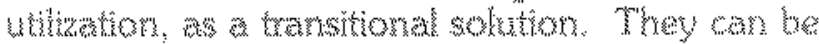
integrated into advancer seneravon cyles the

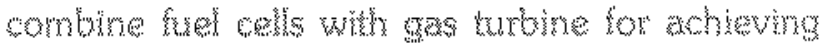

Why

\begin{tabular}{|c|c|}
\hline Winl anergy & 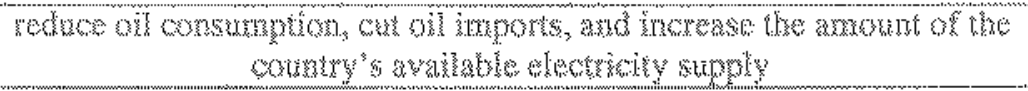 \\
\hline 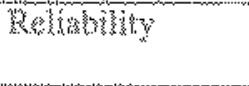 & 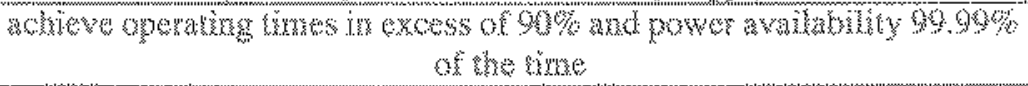 \\
\hline Low operating & 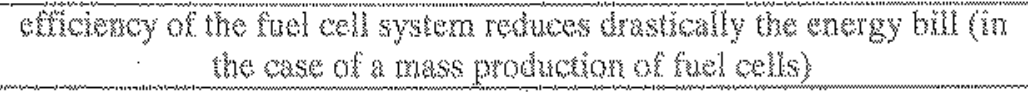 \\
\hline $\begin{array}{l}\text { Constant nowar } \\
\text { probuchion }\end{array}$ & 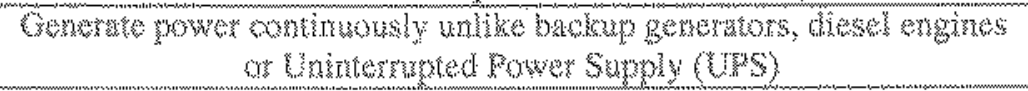 \\
\hline Kenowse of fuet & 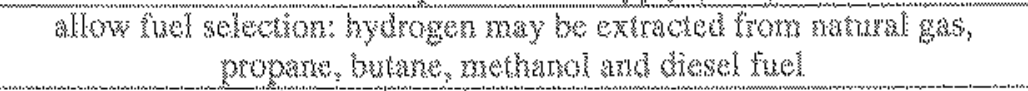 \\
\hline Glean wrissons & 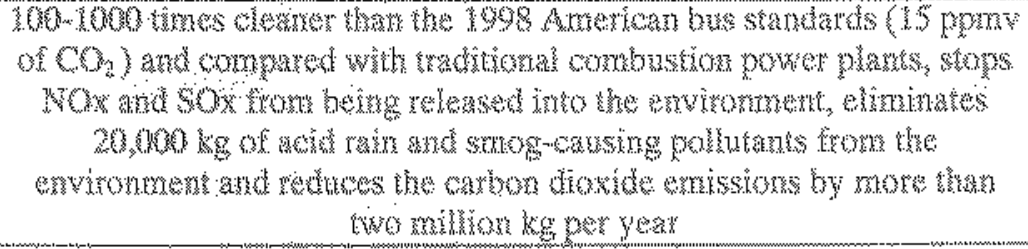 \\
\hline Orater operam & 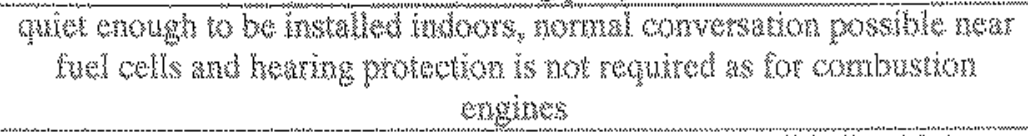 \\
\hline Kigh sfficieney & 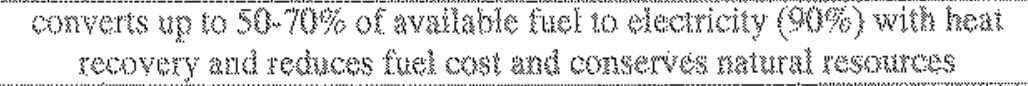 \\
\hline
\end{tabular}


potentially higher efficiencies and lower emissions than the individual system separately. Electrical conversion efficiencies of over $70 \%$ are calculated for these hybrid configurations. The following key areas need to be addressed to produce successfully the desired high performance, lightweight, ambient temperature and pressure, fuel cell system (Chu et.al 2001): (1)Thermal and heat transfer management; (2) Water management; (3) Environment factors; (4) Hydrogen storage conditions; (5) Determination of the optimum stoichiometry of fuel and oxidant; (6) System integration for high-performance PEMFCs.

Several kinds of fuel cell exist but the most important is the PEMFC. This fuel cell uses an acidic membrane electrolyte and gives excellent results, but the price is too expensive and limits the development of this kind of cell. So many systems have been considered to check the possibility of using an anomic exchange membrane or an alkaline solid polymer electrolyte in the fuel cell ( Agel et.al. 2002; Agel et.al 2001). For a fuel other than hydrogen, the sensitivity of the PEMFC to $\mathrm{CO}$ requires the installation of at least two reforms rate purification stages, which results in increasing the volume and complexity of the fuel supply system. The cost of a PEMFC drive train is still expansive as compared with the traditional engine. Lately a direct methanol fuel cell (DMFC) based drive train has been demonstrated in a prototype by Daimler-Chrysler and solid oxide fuel cell as a power unit by BMW.

PEMFC is an emerging technology, which offers many advantages over conventional methods of electricity generation. PEMFC is under development for both transportation and stationary power application. Research efforts are presently focused on issues such as stack performance (Brujin et.al 2002; Lee et.al 2002; Qi et.al 2002; Michael et.al 2002; Jiang \& Chu 2001; Dohle et.al 2001, Robert et.ak 2000; Scholta et.al 1999, Chu \& Jiang 1999; Lee \& Lalk 1998), durability (Ahn et.al 2002; Handley et.al 2002, Peter et.al 2000; Jiang \& Chu 2001), and cost (Dufour 1998; Teagean et.al 1998; Makkus et.al 2000; Teagen et.al 1998; Ayoub Kazim 2002; Xue \& Dong 1998; ). Information on the present status of PEMFC development can be found in (Bar-On 2002; Mackerron 2000; Bird (1996); Stone \& Morrison 2002; Bernay et.al 2002;; Escudero et. al 2002; Handley et.al 2002, Ogdean et.al 1999 Yang et.al 2001).

Further more, these systems offer the best solution for reducing pollution to zero in city centers. Other advantage of PEMFCs include: (1) the flexibility with respect to power and capacityachievable devices for energy conversion and energy storage, (2) the long lifetime and service life, (3) the good ecological balance, and (4) very low selfdischarge.

Table 9: Fuel Cell Power Plant Constraint for Vehicle Application

\begin{tabular}{|l|l|}
\hline $\begin{array}{l}\text { Power plant } \\
\text { Constraints }\end{array}$ & $\begin{array}{l}\text { Corresponding single cell and stack constraints (possibly power, } \\
\text { if significant) }\end{array}$ \\
\hline Mass, Volume & $\begin{array}{l}\text { Single cell and stack power density, stack-operating pressure, fuel } \\
\text { cell power plant density }\end{array}$ \\
\hline System efficiency & Stack and fuel power plant efficiency \\
\hline Cost & $\begin{array}{l}\text { Fuel cell stack raw material and process cost, corresponding } \\
\text { system cost, potential stack fuels }\end{array}$ \\
\hline Kind of fuel & $\begin{array}{l}\text { Acceptable stack contaminant percentage and associated single } \\
\text { cell or stack performance decrease and reversibility }\end{array}$ \\
\hline Emission & Pollutants at the fuel cell stack outlet \\
\hline $\begin{array}{l}\text { Lifetime and } \\
\text { maintenance } \\
\text { operations }\end{array}$ & $\begin{array}{l}\text { Fuel stack lifetime and maintenance operation, fuel stack } \\
\text { operating temperature }\end{array}$ \\
\hline $\begin{array}{l}\text { Starting and } \\
\text { response }\end{array}$ & $\begin{array}{l}\text { Stack, system and power plant thermal management, stack } \\
\text { problems associated with start, stop, sudden power change, stack } \\
\text { performance }\end{array}$ \\
\hline $\begin{array}{l}\text { Safety and } \\
\text { reliability }\end{array}$ & \begin{tabular}{l} 
Stack stop of operation, electrolytes loss, mixing of $\mathrm{H}_{2}-\mathrm{O}_{2}$, etc \\
\hline
\end{tabular}
\end{tabular}




\section{Who}

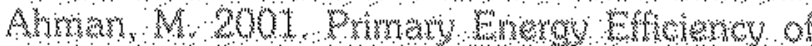

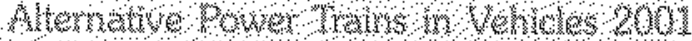
bownd 010 wer $\$ 6$ we $26 \% 78080$

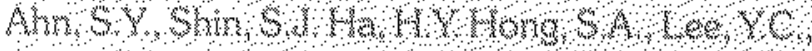
Lin w W and on 142002 ber orrow

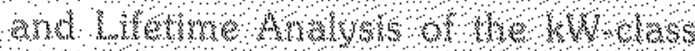

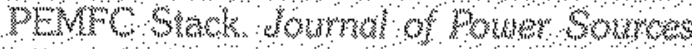
$106(1-2) 295,303$

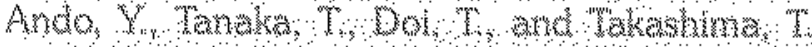
2001 Astudon Themaly Rowenerowe

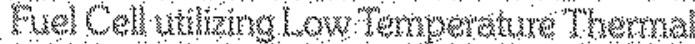

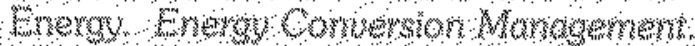
$(20517), 1807,18 \%$

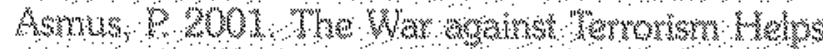

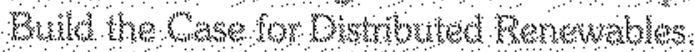

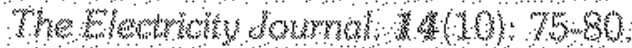

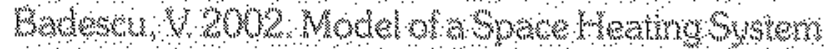

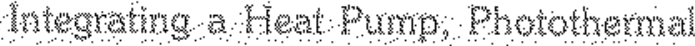

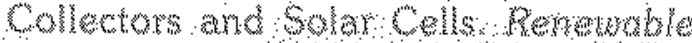
Errergy 274028905

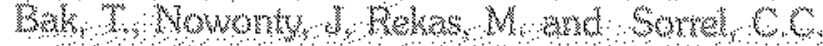

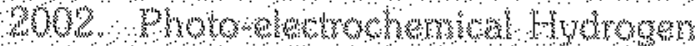

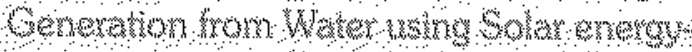

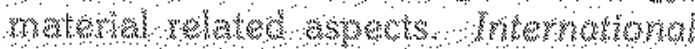

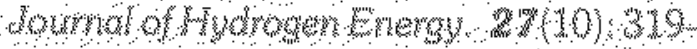
336

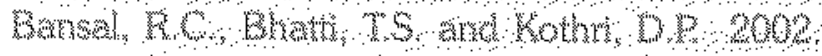

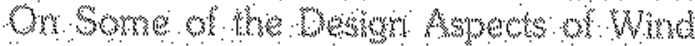

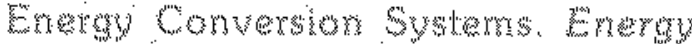

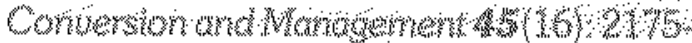
218

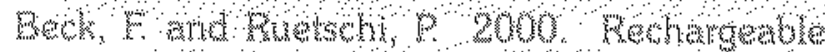

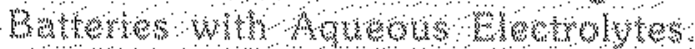

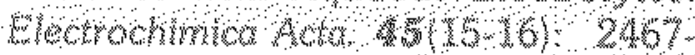
2482

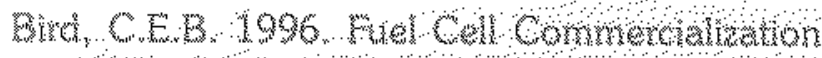

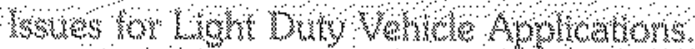

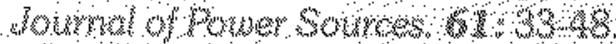

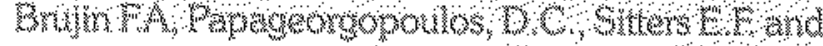

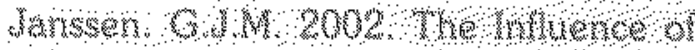

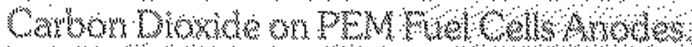

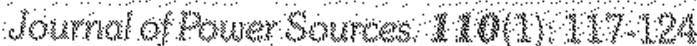

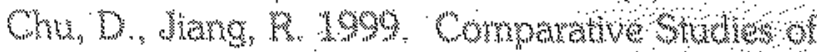

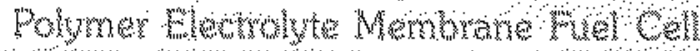
stak and simolowownm of 0 wor Sownos 80.226936

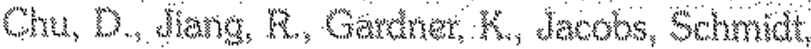

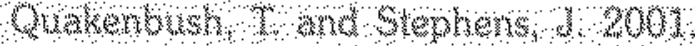

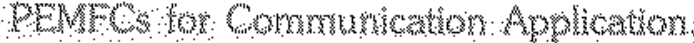

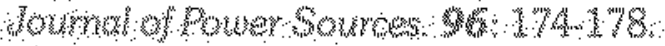

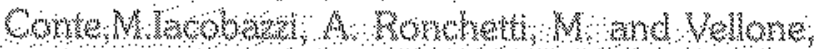

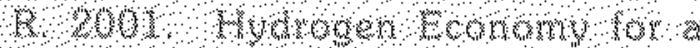

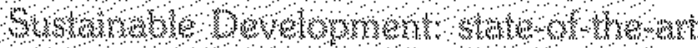

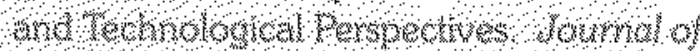

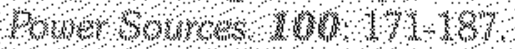

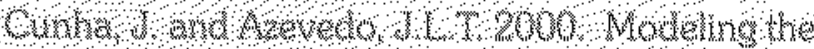

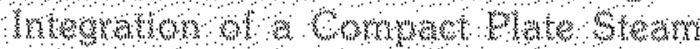

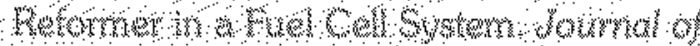
power bow w 60 .

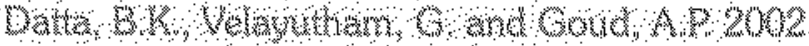

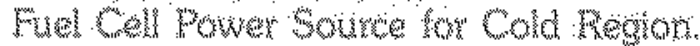
106370376

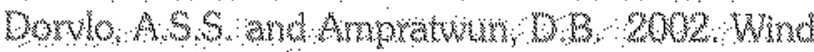

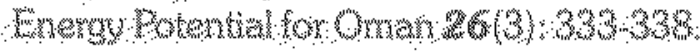

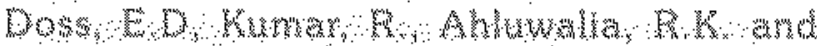

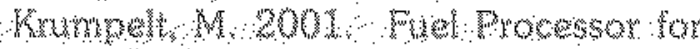

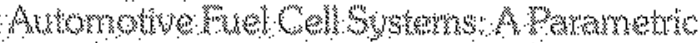

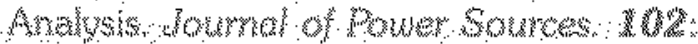
$1+15$

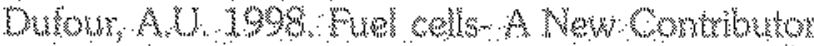

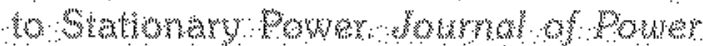
30 mes $71+192$

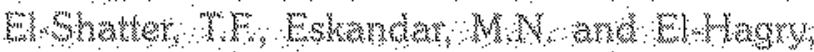

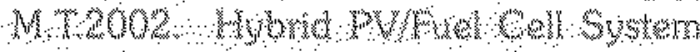

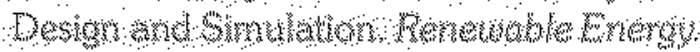
27,4968

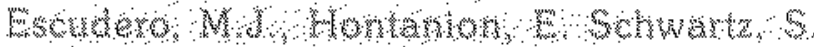

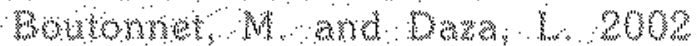
Dewernmer ard performance

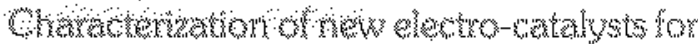

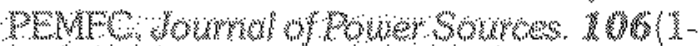
$21.200,24$

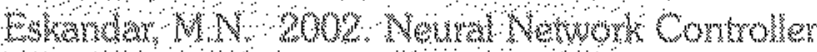
on arwanent Magnet Gemerator Applad mand wrews converwon system

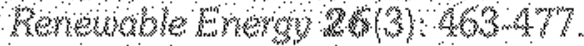

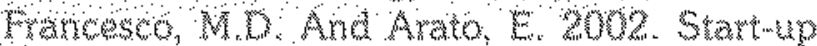

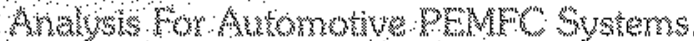

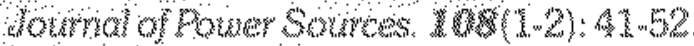

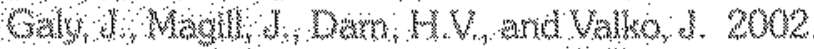

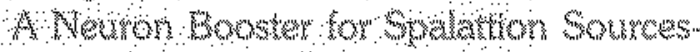

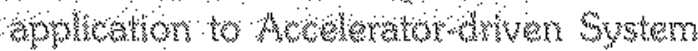

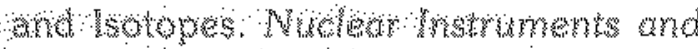

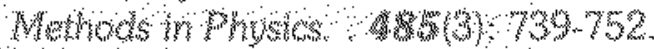

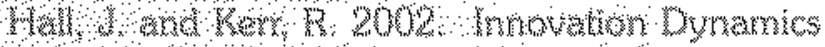

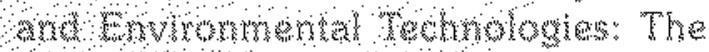

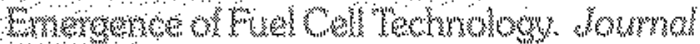

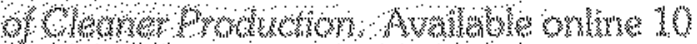
Mavanow. 


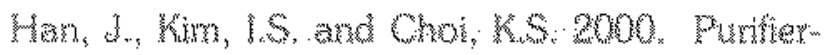
Intewated Methanol Reformer for Fut Coll

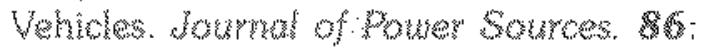
$22322 ?$

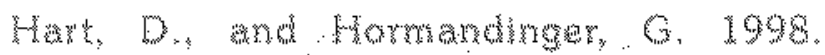

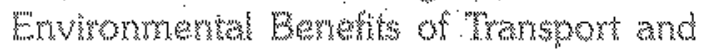

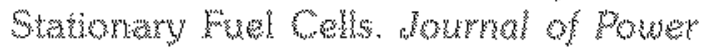
Sources. 72 : 34585

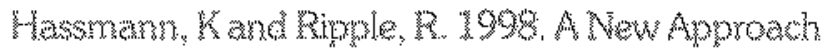

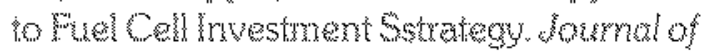
power somks. $71: 75 \%$

Hayner, C. $200 \mathrm{z}$. Simulating Process Setting for Unsaved SOFC Reswonse to Increase im Lno Demand. Woumal of Puwer sources. 109. 363,376

Fetzel, A. Webing. C., Muller, M. Zedda, M. and Mullex, C. 2002. Fuel Cells for Low Apulications. Jommal of Founer sources. $105(2): 148.95$

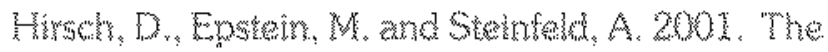
Solar themal Gearbonimation of Nature?

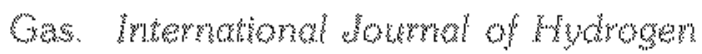

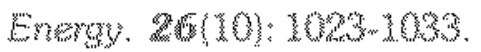

Wohern, B. Boe, M. Hansen, I.B., Brockertyot, P. Colsman, C. Emontis, B. Merrer, R ard Riede, E. 1996. Hystrogen from Methand for linel Cels in Mobite Systems: Devalopment of a Compect Reformer.

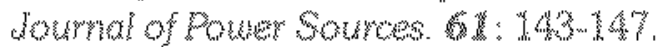

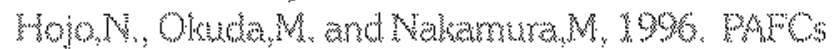

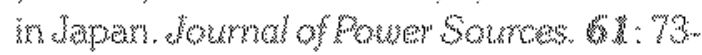
77.

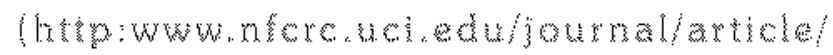

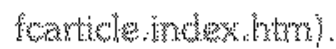

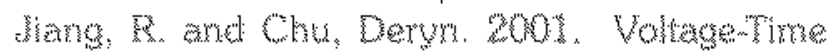
Behavior of a polymer Electrolyte Membrane

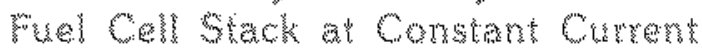
Discharge. Woumul of Pourder Source. 92 . 193.198.

Karyakin, A.A., Morozoy, S.V., Karyakina, E. E.

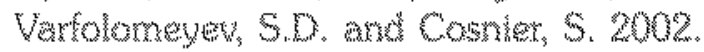

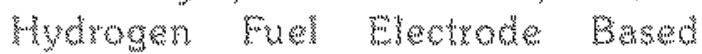
on Biolectrocaturysts by the Errame Hydrogenises. Electrochemisty Communicution. $4(5): 417,420$.

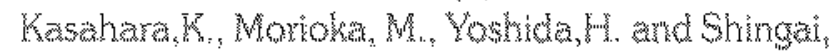
H. 2000. PAFC Operativg Perfomatice

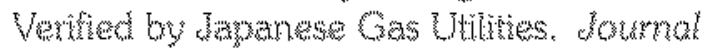

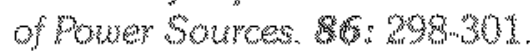

Kaztm, A. 2002. A Novel Aprorow on the Detwrminam of the Minumat Operating
Efficher of PEMFC. Wen wab Energy. $26: 47988$

Lamberhn, D. Lawgurment, Santher, S. and

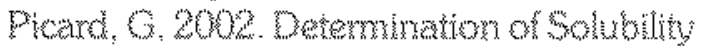

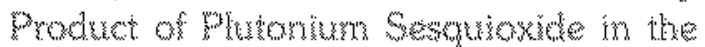

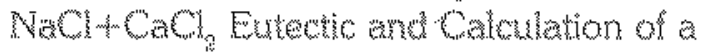
Potentimatup Diagram.

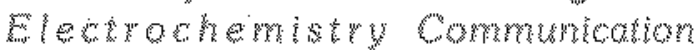
$4(5): 44 \%-450)$

Lamy, C. Lima, A., Lertur, V, Delme, F",

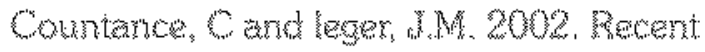
Advances in the Development of Drrect

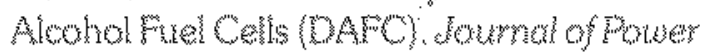
Sources 10 w: $283-296$

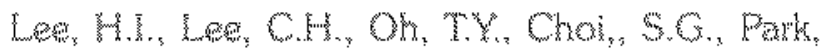

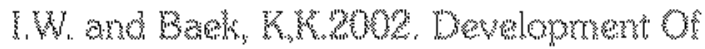
$1 \mathrm{~kW}$ Clas Polyme Fustrolyse Menbrane

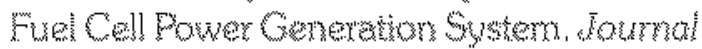

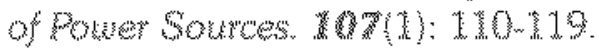

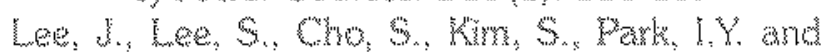
Choi, YD. $200 \%$. Fole of

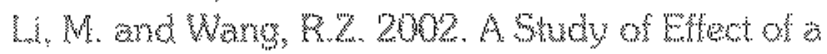

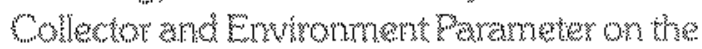
Performance of a solur Power Solv

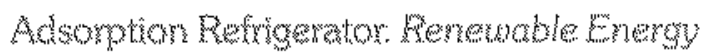
27 (3): 359 982

Ln, 2004 Conceptud Design anc Modsing of

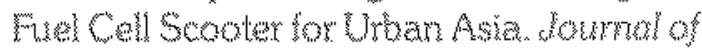
Pouer Sources. 86:202.213.

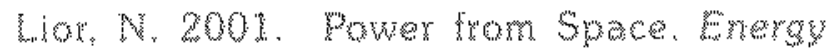

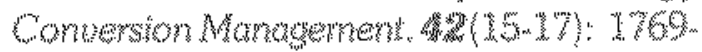
1005

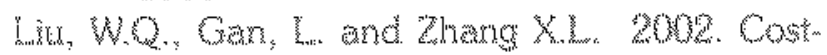
Comperive mentrive for Whd Erergy Development in China: Ir Dynamis and Policy Changes. Evarey

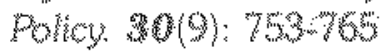

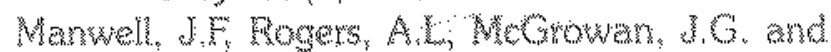
Bailey, B.H. 2002. An Otwhore Wind Resources Assessument Study for New

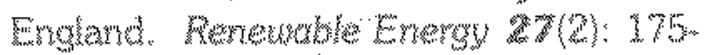
187.

Mckeron, 0.2000 . mimancing Consideratons of Emplothing wual Cell Technology Joumal of

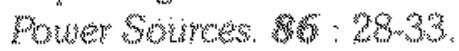

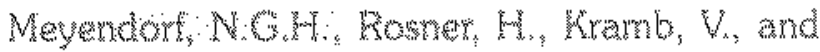

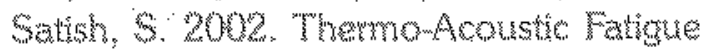

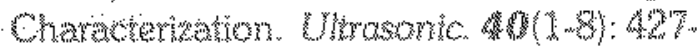
43,

Meyon, J.P and Maynard, H.L. 2002. Design

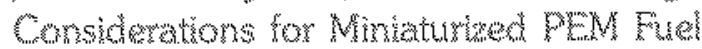




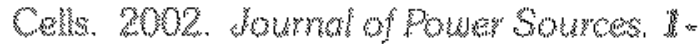
16.

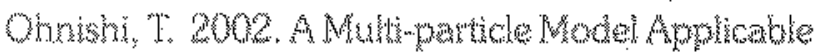
to Socin Issues: "ims - Evaluarion of

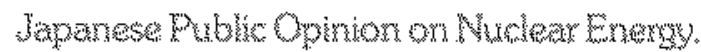

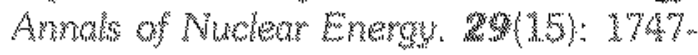
764

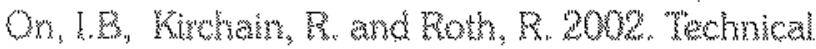
Cost Analysis for PEMFC woumal of Four Som rees a

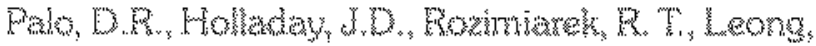

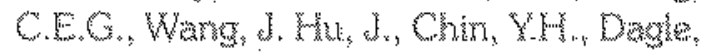

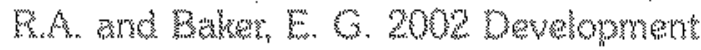
of a Solke potable "uel Cun power Syster". Wounal of prower sources. 08.2834.

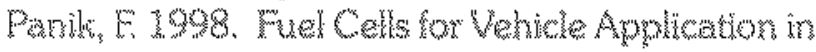

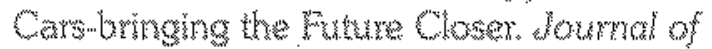
Pouner Sources. 7 : $36-39$.

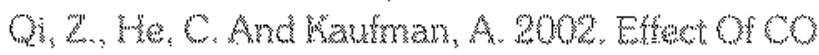
in the Amode bual on whe promance of

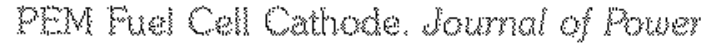
Sources. In press, Unewrewten proot

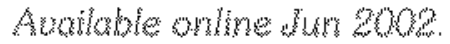

Sammen. NW and bowsma, 2000. Sman Scale

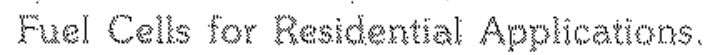

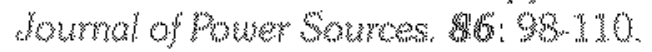

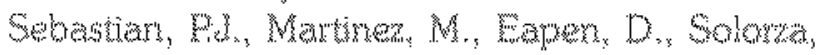
O. and Savologo. 1996 . Hydrogen Energy

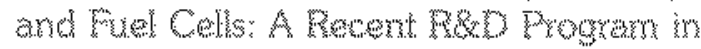

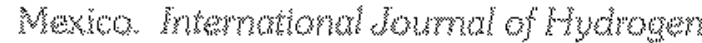

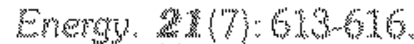

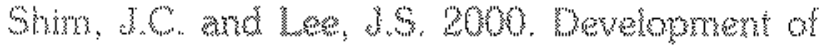
Electrode Strucure ard Analysis of

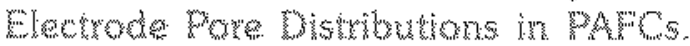

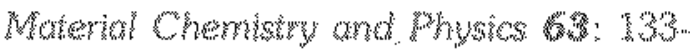
138.

Srook, S. 2000, Heted and Volume Enhanced for

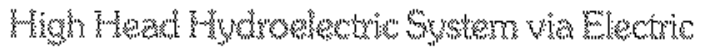
(DC) Generation. and CHe Themal Decompositon with Assistance From Solar

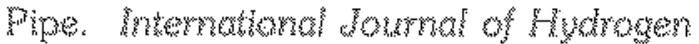
Lnergy. 28 (3): 235.23\%?

Stamboul, A, B. and Travers, w. 2002. Sold Oxide

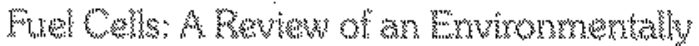

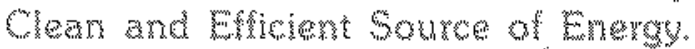
kenewhle ond Sumcinable many Rewews.

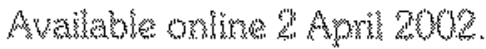

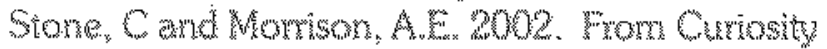

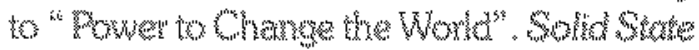
lonics 84ans.

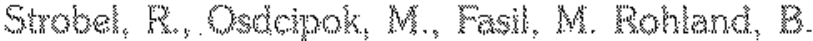
Wriscers and Garche, d. 2002. The Compresuton of Fydrogen in an Electrochermical Coll siased on a PE wivel Cell

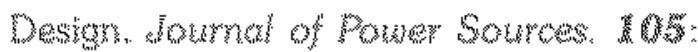
$208 \times 235$

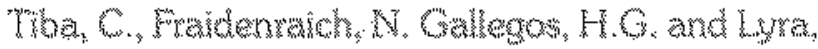
F.M. 2002, solvr Energy Resource

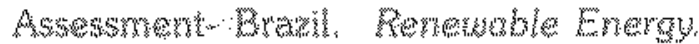
2.

Tributsh, 14. 1997. Chalderge for whotol Electo

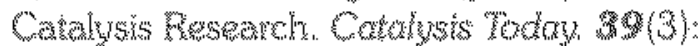
$177 .+186$.

Vanhanem, W. Katurner, PS. and Lund, RD.

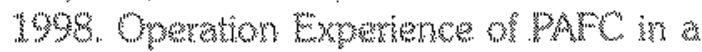

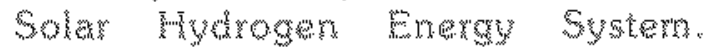

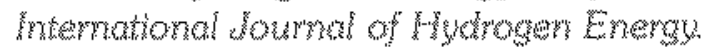
22(7): 707.713.

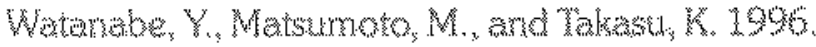

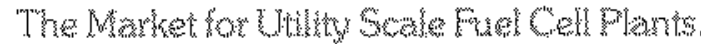

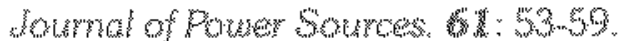

Weiner, S.A. 1998. Fuel Cell Statonary Power Busines Development Jouma of Power Sources. "1 : 61.64 .

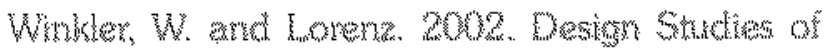

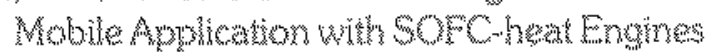

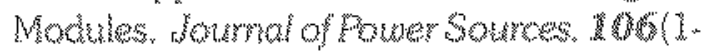
2) $=338393$

Wond Energy Counum. 1998. Survery of Energy Rerources.

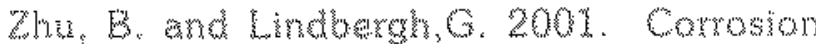

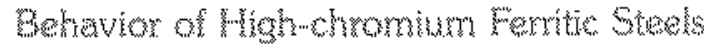
in MC in Cathode 紫n wroment. Elewrochmich Ack wo. 2593-2604. 